\title{
Call for Caution to Consider Babesia bovis and Babesia bigemina as Anthropozoonotic Agents in Colombia. Comment on Kumar et al. The Global Emergence of Human Babesiosis. Pathogens 2021, 10, 1447
}

\author{
Carlos Ramiro Silva-Ramos ${ }^{1}$ and Álvaro A. Faccini-Martínez ${ }^{2,3, * \text { (D) }}$ \\ 1 Grupo de Enfermedades Infecciosas, Departamento de Microbiología, Facultad de Ciencias, \\ Pontificia Universidad Javeriana, Bogotá 110221, Colombia; ramcar007@gmail.com \\ 2 Department of Pathology, University of Texas Medical Branch, Galveston, TX 77550, USA \\ 3 Committee of Tropical Medicine, Zoonoses and Travel Medicine, Asociación Colombiana de Infectología, \\ Bogotá 110221, Colombia \\ * Correspondence: afaccini@gmail.com
}

check for updates

Citation: Silva-Ramos, C.R.; Faccini-Martínez, Á.A. Call for Caution to Consider Babesia bovis and Babesia bigemina as Anthropozoonotic Agents in Colombia. Comment on Kumar et al. The Global Emergence of Human Babesiosis. Pathogens 2021, 10, 1447. Pathogens 2022, 11, 263. https://doi.org/10.3390/ pathogens 11020263

Academic Editors: Estrella Montero, Jeremy Gray, Cheryl Ann Lobo, Luis Miguel González and Lawrence S. Young

Received: 26 January 2022 Accepted: 17 February 2022 Published: 18 February 2022

Publisher's Note: MDPI stays neutral with regard to jurisdictional claims in published maps and institutional affiliations.

Copyright: (C) 2022 by the authors. Licensee MDPI, Basel, Switzerland. This article is an open access article distributed under the terms and conditions of the Creative Commons Attribution (CC BY) license (https:// creativecommons.org/licenses/by/ $4.0 /)$.

\begin{abstract}
Currently, six species and two genetic variants within Babesia genus have been confirmed as human pathogens. Babesia bovis and Babesia bigemina are causative agents of bovine babesiosis, and, in spite of the worldwide distribution of those species and their vectors, no description of related human cases has been reported. As a contribution, we would like to address the articles which claim the alleged role of B. bovis and B. bigemina as anthropozoonotic pathogens in Colombia.
\end{abstract}

Keywords: human babesiosis; Babesia bovis; Babesia bigemina; Colombia

We have read with great interest the review by Kumar et al., "The Global Emergence of Human Babesiosis", published in Pathogens, in which several aspects on the epidemiology of this tick-borne disease are addressed, including the geographic distribution of reported cases and related Babesia species [1].

In Table 2 of their review, Kumar et al. mention the causative agents of human babesiosis throughout the world, designating Babesia bovis and Babesia bigemina as associated with human cases in Colombia, South America [1]. Nevertheless, in the Table's footnote and "Human babesiosis in the Americas" subheading, they highlight that "some causative agents have not been confirmed in larger case series so are not yet accepted as established causes of human babesiosis" and "human babesiosis due to B. bovis and B. bigemina had not previously been described", respectively. In line with the above statements, we would like to address publications which claim the alleged role of these Babesia species as anthropozoonotic pathogens in Colombia [2,3].

Currently, among the more than the 100 Babesia spp. identified in wild and domestic animals worldwide, six species (Babesia microti, Babesia divergens, Babesia duncani, Babesia venatorum, Babesia motasi, and Babesia crassa-like pathogen) and two genetic variants (Babesia divergens-like and Babesia microti-like) have been confirmed as human pathogens [1,4]. Related vectors are anthropophilic ixodid ticks from the temperate regions of the northern hemisphere, in the Ixodes ricinus complex (Ixodes persulcatus, Ixodes ricinus, Ixodes scapularis), as well as Dermacentor albipictus and Ixodes ovatus [1,4]. In contrast, B. bovis and B. bigemina are causative agents of bovine babesiosis, which affect cattle and buffaloes, causing severe disease of considerable economic impact due to loss of meat production and death of infected animals [5]. These bovine babesiae are transmitted by Rhipicephalus (Boophilus) tick species, which are widespread in tropical and subtropical regions [6].

Curiously, in spite of the worldwide distribution of B. bovis, B. bigemina, and their vectors $[5,6]$, no description of related human cases have been reported, beyond the Colombian 
studies by Ríos et al. [2] and González et al. [3]. The former described seven farm workers, with or without malaria-like symptoms, from Puerto Berrío municipality (Antioquia department) with IgM or IgG antibodies to Babesia sp. by IFA test, using B. bovis and B. bigemina antigens [2]. All but one had negative IgM/IgG antibodies to Plasmodium falciparum by IFA and ELISA tests [2]. One of the symptomatic individuals, in addition to an IgM titer of 64 to $B$. bovis, presented pyriform parasites in pairs and tetrads without pigment in a thin blood smear, suggesting Babesia infection [2].

While this patient could be a probable babesiosis case considering the blood smear finding, a positive serological result to $B$. bovis does not necessarily indicate a specific infection with this Babesia, but rather, an exposure to an unknown Babesia sp. or even a cross-reaction $[7,8]$. Indeed, despite the fact that Puerto Berrío municipality is an endemic area for P. falciparum and Plasmodium vivax malaria [9], Ríos et al. did not include this latter Plasmodium species in order to rule out false positive results by B. bovis and B. bigemina IFA testing [2]. In this sense, interestingly, in 1972, Ludford et al. demonstrated that 3/20 individuals throughout the course of an induced P. vivax infection developed antibodies to $B$. bovis of equal or higher titer than those to $P$. vivax, and lower or negative titers to P. falciparum [10].

Regarding the other Colombian study, González et al., using molecular, microscopic and serological methods, investigated B. bovis and B. bigemina infection in 300 humans involved in cattle raising from Turbo and Necoclí municipalities, Antioquia department [3]. Overall, four (1.3\%) and two $(0.6 \%)$ individuals studied for possible infection with $B$. bovis and B. bigemina, respectively, were detected by PCR of venous blood samples [3]. In peripheral blood smears, parasitic forms suggesting Babesia spp. were observed in two individuals from the $B$. bovis positive-PCR group and one individual from the $B$. bigemina positive-PCR group [3]. In addition, the authors reported detection of antibodies for both bovine babesiae in one subject $(0.3 \%)$, by ELISA and IFA tests, using B. bovis and B. bigemina antigens [3].

Similarly, as in the Rios et al. study, González et al. described Turbo and Necoclí municipalities as malaria endemic areas [3]; nevertheless, they did not rule out potential serological cross-reaction between B. bovis/B. bigemina and Plasmodium spp. [10]. Moreover, regarding molecular detection, González et al. used a species-specific nested-PCR, with expected products of $291 \mathrm{bp}$ for B. bovis and $178 \mathrm{bp}$ for B. bigemina of the $18 \mathrm{~S}$ gene, and subsequent sequencing [3]. The authors did not mention the positive controls that we assume were B. bovis/B. bigemina DNA. Thus, it is well known that nested PCR testing is generally more prone to false positive results [11], and unfortunately, the manuscript does not provide information on generated sequences of the six positive human samples, which would have been valuable in order to confirm that it was not the result of contamination. Regarding this, even excluding contamination, humans could be participating as merely accidental hosts rather than playing a role in the parasite life cycle itself, as B. bovis and B. bigemina might be able to undergo a few replication cycles in the human blood, but then die [12].

Due to the worldwide emergence of some infectious diseases, the presence of human pathogenic Babesia spp. in Colombia must not be totally discarded. However, the epidemiology of human babesiosis is not different from other vector-borne diseases, which are highly related to the geographic distribution of their arthropod vectors [1]. Thus, as mentioned, for human pathogenic babesiae, the vectors are anthropophilic ixodid ticks from the temperate regions of the northern hemisphere, and none of them have been found in tropical regions, including Colombia $[13,14]$. In addition, it is noteworthy that R. microplus, the main vector of B. bovis and B. bigemina in the Neotropical Region [6], is a sporadic anthropophilic tick [15].

Finally, and interestingly, confirmed cases of human babesiosis due to B. microti or B. microti-like protozoa have been reported in South America (Bolivia and Ecuador) $[16,17]$ and in Mexico [18]. Thus, in addition to the well-known cross-reactivity which occurs between $B$. microti and B. bovis/B. bigemina $[7,8]$, the fact that $B$. microti or a phylogenetically 
related species has been detected in human cases in these geographic regions implies that at least one zoonotic Babesia sp. is circulating in tropical countries, generating the question of what the tick vector is; an issue deserving further studies. However, according to the currently available worldwide data, the claim of B. bovis and B. bigemina as etiological agents of human babesiosis should not yet be considered until further scientific evidence demonstrates their potential as anthropozoonotic pathogens.

Author Contributions: Á.A.F.-M. conceived the manuscript; C.R.S.-R. and Á.A.F.-M. designed the manuscript; C.R.S.-R. and Á.A.F.-M. wrote the paper. All authors have read and agreed to the published version of the manuscript.

Funding: This research received no external funding.

Institutional Review Board Statement: Not applicable.

Informed Consent Statement: Not applicable.

Data Availability Statement: Not applicable.

Acknowledgments: We wish to thank David H. Walker for proofreading, editing, and providing feedback on the manuscript.

Conflicts of Interest: The authors declare no conflict of interest.

\section{References}

1. Kumar, A.; O’Bryan, J.; Krause, P.J. The global emergence of human babesiosis. Pathogens 2021, 10, 1447. [CrossRef] [PubMed]

2. Ríos, L.; Alvarez, G.; Blair, S. Serological and parasitological study and report of the first case of human babesiosis in Colombia. Rev. Soc. Bras. Med. Trop. 2003, 36, 493-498. [CrossRef] [PubMed]

3. Gonzalez, J.; Echaide, I.; Pabón, A.; Gabriel Piñeros, J.J.; Blair, S.; Tobón-Castaño, A. Babesiosis prevalence in malaria-endemic regions of Colombia. J. Vector Borne Dis. 2018, 55, 222-229. [CrossRef] [PubMed]

4. Krause, P.J. Human babesiosis. Int. J. Parasitol. 2019, 49, 165-174. [CrossRef] [PubMed]

5. Suarez, C.E.; Noh, S. Emerging perspectives in the research of bovine babesiosis and anaplasmosis. Vet. Parasitol. 2011, 180, 109-125. [CrossRef] [PubMed]

6. Gray, J.S.; Estrada-Peña, A.; Zintl, A. Vectors of babesiosis. Annu. Rev. Entomol. 2019, 64, 149-165. [CrossRef] [PubMed]

7. Chisholm, E.S.; Ruebush, T.K., 2nd; Sulzer, A.J.; Healy, G.R. Babesia microti infection in man: Evaluation of an indirect immunofluorescent antibody test. Am. J. Trop. Med. Hyg. 1978, 27, 14-19. [CrossRef] [PubMed]

8. Chisholm, E.S.; Sulzer, A.J.; Ruebush, T.K., 2nd. Indirect immunofluorescence test for human Babesia microti infection: Antigenic specificity. Am. J. Trop. Med. Hyg. 1986, 35, 921-925. [CrossRef] [PubMed]

9. Tobón-Castaño, A.; Betancur, J.E. Malaria grave en mujeres gestantes hospitalizadas entre el 2010 y el 2014 en el departamento de Antioquia, Colombia. Biomedica 2019, 39, 354-369. [CrossRef] [PubMed]

10. Ludford, C.G.; Hall, W.T.; Sulzer, A.J.; Wilson, M. Babesia argentina, Plasmodium vivax and P. falciparum: Antigenic cross-reactions. Exp. Parasitol. 1972, 32, 317-326. [CrossRef]

11. Wormser, G.P.; Marques, A.; Pavia, C.S.; Schwartz, I.; Feder, H.M.; Pachner, A.R. Lack of convincing evidence that Borrelia burgdorferi infection causes either Alzheimer's disease or Lewy body dementia. Clin. Infect. Dis. 2021, 29, ciab993. [CrossRef] [PubMed]

12. Schnittger, L.; Rodriguez, A.E.; Florin-Christensen, M.; Morrison, D.A. Babesia: A world emerging. Infect. Genet. Evol. 2012, 12, 1788-1809. [CrossRef] [PubMed]

13. Guglielmone, A.A.; Beati, L.; Barros-Battesti, D.M.; Labruna, M.B.; Nava, S.; Venzal, J.M.; Mangold, A.J.; Szabó, M.P.; Martins, J.R.; González-Acuña, D.; et al. Ticks (Ixodidae) on humans in South America. Exp. Appl. Acarol. 2006, 40, 83-100. [CrossRef] [PubMed]

14. Guglielmone, A.A.; Nava, S.; Robbins, R.G. Chapter 1, Prostriata Group: Genus Ixodes. In Neotropical Hard Ticks (Acari: Ixodida: Ixodidae), A Critical Analysis of Their Taxonomy, Distribution, and Host Relationships; Springer: Cham, Switzerland, 2021. [CrossRef]

15. Guglielmone, A.A.; Nava, S.; Robbins, R.G. Chapter 3, Metastriata: Genera Dermacentor, Haemaphysalis, and Rhipicephalus. In Neotropical Hard Ticks (Acari: Ixodida: Ixodidae), A Critical Analysis of Their Taxonomy, Distribution, and Host Relationships; Springer: Cham, Switzerland, 2021. [CrossRef]

16. Gabrielli, S.; Totino, V.; Macchioni, F.; Zuñiga, F.; Rojas, P.; Lara, Y.; Roselli, M.; Bartoloni, A.; Cancrini, G. Human babesiosis, Bolivia, 2013. Emerg. Infect. Dis. 2016, 22, 1445-1447. [CrossRef] [PubMed]

17. Al Zoubi, M.; Kwak, T.; Patel, J.; Kulkarni, M.; Kallal, C.A. Atypical challenging and first case report of babesiosis in Ecuador. IDCases 2016, 4, 15-17. [CrossRef] [PubMed]

18. Peniche-Lara, G.; Balmaceda, L.; Perez-Osorio, C.; Munoz-Zanzi, C. Human babesiosis, Yucatán State, Mexico, 2015. Emerg. Infect. Dis. 2018, 24, 2061-2062. [CrossRef] [PubMed] 